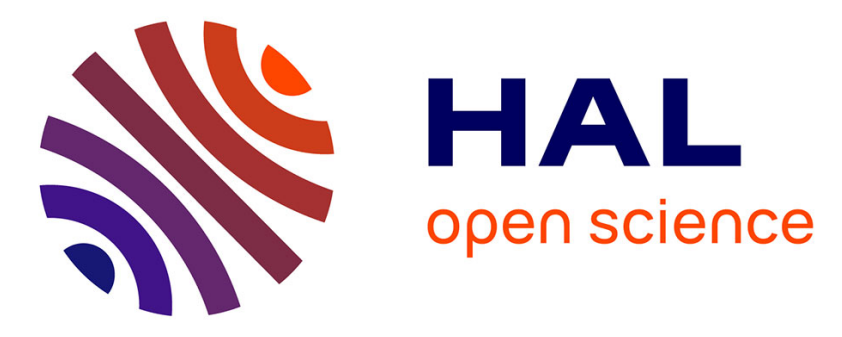

\title{
Synergy between iodide ions and mangrove tannins as inhibitors of mild steel corrosion
}

\author{
Mohd Ridhwan Adam, Afidah Abdul Rahim, Affaizza Mohamad Shah
}

\section{To cite this version:}

Mohd Ridhwan Adam, Afidah Abdul Rahim, Affaizza Mohamad Shah. Synergy between iodide ions and mangrove tannins as inhibitors of mild steel corrosion. Annals of Forest Science, 2015, 72 (1), pp.9-15. 10.1007/s13595-014-0398-9 . hal-01284155

\section{HAL Id: hal-01284155 \\ https://hal.science/hal-01284155}

Submitted on 7 Mar 2016

HAL is a multi-disciplinary open access archive for the deposit and dissemination of scientific research documents, whether they are published or not. The documents may come from teaching and research institutions in France or abroad, or from public or private research centers.
L'archive ouverte pluridisciplinaire $\mathbf{H A L}$, est destinée au dépôt et à la diffusion de documents scientifiques de niveau recherche, publiés ou non, émanant des établissements d'enseignement et de recherche français ou étrangers, des laboratoires publics ou privés. 


\title{
Synergy between iodide ions and mangrove tannins as inhibitors of mild steel corrosion
}

\author{
Mohd Ridhwan Adam • Afidah Abdul Rahim • \\ Affaizza Mohamad Shah
}

Received: 8 November 2013 / Accepted: 12 June 2014 /Published online: 4 July 2014

(C) INRA and Springer-Verlag France 2014

\begin{abstract}
- Context Corrosion of materials is a problem faced by many industries. One of the solutions to this problem is to apply corrosion inhibitors.

- Aims In this study, the synergy between iodide ions and mangrove tannin extracted from mangrove bark (waste products of the charcoal industry) was tested on the inhibition of corrosion of mild steel in $0.5 \mathrm{M} \mathrm{HCl}$ and $0.25 \mathrm{M} \mathrm{H}_{2} \mathrm{SO}_{4}$. It was compared with the inhibition provided by mimosa and chestnut tannins.

- Methods Potentiodynamic and electrochemical impedance were recorded under various temperatures from 30 to $60^{\circ} \mathrm{C}$ in order to obtain the activation energy (Ea), the activated enthalpy $(\Delta \mathrm{H})$ and the activated entropy $(\Delta \mathrm{S})$.

- Results The results showed that there was an increase in inhibition efficiency when iodide ions were added to corrosive media in the presence of mangrove tannin. The effect decreased when temperature increased. Mangrove tannins showed comparable inhibitive properties to those of commercial mimosa and chestnut tannins.

- Conclusion Inhibition efficiency of tannins as inhibitors of corrosion for mild steel in acidic media was improved by the addition of iodide ions. Tannins extracted from mangrove bark were more efficient than those from mimosa and chestnuts.
\end{abstract}

Keywords Synergistic effect · Mangrove tannin ·

Thermodynamic

Handling Editor: Jean-Michel Leban

Contribution of the co-authors Afidah Abdul Rahim: supervising the work and writing the paper.

Mohd Ridhwan Adam: designing the experiment, running the data analysis, and writing the paper.

Affaizza Mohamad Shah: writing the paper.

M. R. Adam • A. A. Rahim $(\varangle) \cdot$ A. M. Shah

School of Chemical Sciences, Universiti Sains Malaysia, 11800

Minden, Penang, Malaysia

e-mail: afidah@usm.my

\section{Introduction}

Metals and alloys are normally used for a wide range of purposes that are normally designed for long-term applications. Mild steel is one of the most used metal alloys in automobile, water treatment, and construction industries. However, long exposures of this metal in the corrosive media and environments have led to the corrosion of these metal alloys (Prabhu et al. 2008). As a consequence, the lifetime of mild steels will be shortened, and this problem leads to other serious problems that includes the loss of life due to accidents (Davis 2000). The corrosion processes are usually caused by the interactions between the metal and its surroundings. Corrosion of metals is an electrochemical reaction which can cause the damage and deterioration of the physical and chemical properties of the attacked metals or alloys (Winston 2000; Syed 2006).

Some of the typical corrosive media are humid air, water (fresh, distilled, salted, and marine), acids, bases as well as soil, steam, and gases. Strong acids such as hydrochloric and sulphuric acids are widely used in industries for many purposes, especially in cleaning, de-scaling, and pickling procedures. The corrosion scientists have employed many methods to control corrosion processes. One of the most practical methods is the use of corrosion inhibitors (Winston 2000).

Although the use of corrosion inhibitors will reduce undesirable acid metal dissolution, inorganic inhibitors are harmful to the environment due to their toxicity. Therefore, there is now a focus on the development of nontoxic inhibitors as alternatives to replace inorganic inhibitors. Several investigations have been reported on the use of plant extracts containing alkaloids and polyphenolic compounds as well as carbohydrates as inhibitors (Rahim and Kassim 2008; Raja and Sethuraman 2008). It has been reported that most of the effective inhibitors possess an active functional group such as nitro $\left(-\mathrm{NO}_{2}\right)$ or hydroxyl $(-\mathrm{OH})$ groups such as in tannins. Tannins extracted from mangrove (Rhizophora Apiculata Blume) bark are phenolic compounds with high molecular 
masses. Afidah (2009) previously identified mangrove tannins as condensed tannins. Mangrove tannins have been found to contain high proportions of procyanidins to prodelphinidins with the predominant interflavanoid linkages of C4-C8; it has also been found that flavanoid units with cis-configuration at $\mathrm{C} 2$ and $\mathrm{C} 3$ form- the bulk of the oligomers, and that mangrove tannin oligomers have complex structures with high degree of polymerisation from the trimers to decamers that correspond to the molecular weight up to 3,000 Da. Multiple groups of hydroxyphenolics enable the formation of tannin complexes with protein, metal ions, and other macromolecules.

Most of the acidic inhibitors are specific in action. However, the efficiencies of these inhibitors can be further enhanced with the addition of other substances or in combination with other inhibitors. The introduction of halide ions has been found to enhance the inhibition efficiency of organic inhibitors synergistically (Pavithr et al. 2010). It is generally agreed that the addition of halide ions to corrosive media has increased the ability of adsorption of organic cations by forming interconnecting bridges between negatively charged metal surfaces and inhibitor cations.

There are many techniques used in determining and measuring the corrosion rate of metals. Previously, the weight loss method, sometimes known as the gravimetric method, was the only conventional method used for corrosion measurements. However, as the research world becomes more sophisticated, modern technology has led to the development of electrochemical measurements. These time-saving measurements have produced some comparative results to the conventional gravimetric method.

Various tannins, especially mangrove tannin, have been found to be good corrosion inhibitors for mild steel in acidic media (Rahim et al. 2007, 2008, 2011; Rahim and Kassim 2008). As such, in this present work, the inhibition efficiency of mangrove (Rhizophora Apiculata Blume) tannin (MgT) in relation to the corrosion of mild steel in $0.5 \mathrm{M} \mathrm{HCl}$ and $0.25 \mathrm{M}$ $\mathrm{H}_{2} \mathrm{SO}_{4}$ solutions has been studied. Enhancement of the inhibition efficiency of this tannin was attempted through the addition of iodide ions to the tannin solution. The inhibition efficiencies obtained were then compared with those of commercial mimosa $(\mathrm{MmT})$ and chestnut tannins $(\mathrm{CnT})$ in all media studied.

\section{Material and methods}

\subsection{Material preparation}

Tests were performed on mild steel sheets with weight percentage compositions as follows: $\mathrm{C}, 0.205 ; \mathrm{Mn}, 0.55 ; \mathrm{Si}, 0.06$; , 0.039 ; Fe, balance. The sheets $(0.1 \mathrm{~cm}$ thickness $)$ were mechanically cut into dimensions of $3.0 \mathrm{~cm} \times 3.0 \mathrm{~cm}$ for all studies. The studied surface was wet-polished with silicon carbide abrasive paper (from grade 400 to 1,200), rinsed with double distilled water, and degreased in acetone and dried in warm air.

\subsection{Inhibitor preparation}

Finely ground mangrove (Rhizophora Apiculata Blume) bark powder was mixed with $70 \%$ acetone and stirred for $24 \mathrm{~h}$. The extract was then concentrated at $40^{\circ} \mathrm{C}$ under reduced pressure in a rotary evaporator to remove the acetone. Then, the concentrated extract was frozen for $24 \mathrm{~h}$ before being freeze-dried for $48 \mathrm{~h}$. The test inhibitor mangrove tannin obtained was dissolved in $0.5 \mathrm{M} \mathrm{HCl}$ and $0.25 \mathrm{M} \mathrm{H}_{2} \mathrm{SO}_{4}$ solutions to obtain the desired concentration $\left(3.0 \mathrm{~g} \mathrm{l}^{-1}\right)$. Potassium iodide (KI) solution $(0.1 \mathrm{M})$ was prepared as a blank solution and added to $3.0 \mathrm{~g}^{-1}$ mangrove tannin. Mimosa and chestnut tannins from SILVACHIMICA, Italy were used as received.

\subsection{Electrochemical measurements}

Electrochemical measurements were conducted in a conventional 100-ml three-electrode cell. Mild steel coupons with dimensions of $30.0 \mathrm{~mm} \times 30.0 \mathrm{~mm} \times 1.0 \mathrm{~mm}$ were used as a working electrode, while a saturated calomel electrode (SCE) and a platinum electrode were used as the reference and counter electrodes respectively. The experiments were carried out using Potentiostat/Galvanostat/ZRA Model Gamry Reference 600 , and the data were analysed using Gamry Instrument Framework version 5.67 software. Prior to each measurement, the electrodes were held in the test solution at the natural potential for $30 \mathrm{~min}$, providing sufficient time for corrosion potential $\left(\mathrm{E}_{\mathrm{corr}}\right)$ to attain a stable state. All electrochemical experiments were carried out at $30,40,50$, and $60^{\circ} \mathrm{C}$ respectively in order to obtain the thermodynamic data, and they were carried out in duplicates.

\subsubsection{Potentiodynamic polarization measurement}

Potentiodynamic polarisation measurements have been used to determine the effects of inhibitor concentrations on the anodic and cathodic polarisation behaviours of mild steels in $0.5 \mathrm{M} \mathrm{HCl}$ and $0.25 \mathrm{M} \mathrm{H}_{2} \mathrm{SO}_{4}$ solutions. The potentiodynamic polarisation measurements were carried out from a cathodic potential of $-0.2 \mathrm{~V}$ to an anodic potential of $+0.2 \mathrm{~V}$ with respect to the $E_{\text {corr }}$, at a sweep rate of $1 \mathrm{mVs}^{-1}$. The respective electrochemical parameters calculated are corrosion potential $\left(\mathrm{E}_{\mathrm{corr}}\right)$, anodic and cathodic Tafel slopes $\left(\beta_{\mathrm{a}}\right.$ and $\left.\beta_{\mathrm{c}}\right)$, and corrosion current density $\left(i_{\text {corr }}\right)$, which were obtained from the extrapolation of the anodic and cathodic Tafel curves towards $\mathrm{E}_{\text {corr }}$ The $\%$ IE was obtained from the measured $i_{\text {corr }}$ by using the following relationship:

$\% I E=\frac{i^{\mathrm{o}}-i}{i^{\mathrm{o}}} \times 100$ 
where $i$ and $i^{o}$ are the inhibited and uninhibited corrosion current densities of mild steel respectively.

\subsubsection{Electrochemical impedance spectroscopy measurement}

Electrochemical impedance spectroscopy (EIS) measurements were made at corrosion potential $\left(E_{c o r r}\right)$ over the frequency range from 100,000 to $0.1 \mathrm{~Hz}$ at an amplitude of $10 \mathrm{mV}$ and a scan rate of 10 points per decade. The Nyquist representations of the impedance data were analysed with ZSimpWin software. The charge transfer resistance $\left(R_{c t}\right)$ was obtained by fitting the Nyquist semicircle plots to the equivalent circuit by using the Zsimp version 3.22 software. The \% IE of the inhibitor was calculated from the following equation;

$\% I E=\frac{R_{c t}-R_{c t}^{\prime}}{R_{c t}} \times 100$

Where $R_{c t}$ is the charge transfer resistance values of mild steel in the absence of the inhibitor and and $R_{c t}^{\prime}$ is the charge transfer resistance values of mild steel in the presence of inhibitors.

\subsection{Comparison study of the inhibitory effect with several tannins}

Electrochemical tests as previously described were carried out using commercial mimosa and chestnut tannins. The synergistic effects of these two tannins were studied at an optimum concentration of tannins $\left(3 \mathrm{~g} \mathrm{l}^{-1}\right.$ or $\left.2 \mathrm{~g}^{-1}\right)$ and iodide ions $(0.1 \mathrm{M})$.

\section{Results}

\subsection{Potentiodynamic polarisation measurements}

The results obtained from this measurement are represented in the form of Tafel plots and shown in Figs. 1 and 2. The \% IE values were calculated using the $i_{\text {corr }}$ values obtained from the measurements as previouly described in section 2.3.1. The electrochemical parameters obtained from the extrapolation of the Tafel plots in both media studied were tabulated, and are shown in Table 1.

From Table 1, it can be observed that the values of \% IE of mangrove tannin alone are $89 \%$ and $78 \%$ in $\mathrm{HCl}$ and $\mathrm{H}_{2} \mathrm{SO}_{4}$ respectively, and have significantly increased to $94 \%$ for both acidic solutions, upon the addition of iodide ions to mangrove tannin. This indicates that a synergistic effect had occurred between the mangrove tannin and the iodide ions. In addition, the data obtained from the polarisation measurements of mimosa tannin and chestnut tannin also revealed the same trend, where the $\%$ IE increased from $93 \%$ to $95 \%$ as the iodide ions were added to both acidic solutions containing both tannins.

\subsection{Electrochemical impedance spectroscopy measurements}

These measurements were undertaken to assess the interactions of the mild steel/electrolyte interface in the presence and absence of tannins with and without the addition of iodide ions. The data obtained are represented as Nyquist plots and shown in Figs. 3 and 4. The parameters from these analyses are tabulated in Table 2. From Table 2, it can be seen that the $\mathrm{R}_{\mathrm{ct}}$ values increased as the concentrations of mangrove tannin increased, thus it resulted in the increment of \% IE. The increment in \% IE values up to $92 \%$, as compared to the mangrove tannin alone ( $84 \%$ ), has indicated that there was a synergistic effect between the tannin and the iodide ions. The combinations of iodide with mimosa tannin and chestnut tannin were performed in both acids and similar trends had also been observed. All data obtained are in good agreement with those obtained in the potentiodynamic polarisation analyses.

\subsection{Temperature studies of corrosion inhibition effect of tannins and iodide ions}

The thermodynamic and kinetic data that were obtained from both electrochemical measurements in both corrosive media are tabulated in Tables 3 and 4. Table 3 summarises the corresponding efficiencies of mangrove tannin in combination with $0.1 \mathrm{M} \mathrm{KI}$ at various temperatures in $0.5 \mathrm{M} \mathrm{HCl}$ and $0.25 \mathrm{M} \mathrm{H}_{2} \mathrm{SO}_{4}$ respectively. As the inhibitors were added into the corrosive media, the \% IE values have slightly decreased, while the corrosion rate $(\mathrm{CR})$ and current density $\left(\boldsymbol{i}_{\text {corr }}\right)$ increased significantly as the temperatures increased.

The variations of natural logarithms of the corrosion rate against the absolute temperature in the absence and presence of inhibitors in $0.5 \mathrm{M} \mathrm{HCl}$ and $0.25 \mathrm{M} \mathrm{H}_{2} \mathrm{SO}_{4}$ solutions were plotted (not shown). From these plots, it was found that the activation energies, $E_{a}$ values (Table 4) in the presence of all tannins were higher than the values obtained without the inhibitors in both media. In $0.5 \mathrm{M} \mathrm{HCl}$ medium, the $\mathrm{E}_{\mathrm{a}}$ values obtained by all three tannins were in the range $98.51-112.90 \mathrm{~kJ} \mathrm{~mol}^{-1}$, which were higher than the blank $\left(67.14 \mathrm{~kJ} \mathrm{~mol}^{-1}\right)$. The same trends were shown by $0.25 \mathrm{M} \mathrm{H}_{2} \mathrm{SO}_{4}$ solutions, where the $\mathrm{E}_{\mathrm{a}}$ values in the presence of all inhibitors were higher than those obtained in the absence of these inhibitors.

\section{Discussion}

\subsection{Potentiodynamic polarisation measurements}

From the results obtained, it can be clearly seen that the presence of all tannins in both media had decreased both anodic and cathodic current densities as compared to that of the respective blank solutions. The decrease in current 
Fig. 1 Tafel plots of mild steel in $0.5 \mathrm{M} \mathrm{HCl}$ in the absence and presence of mangrove tannin $(\mathrm{MgT})$, mimosa $(\mathrm{MmT})$ and chestnut (CnT) tannins alone and in combination with iodide ions

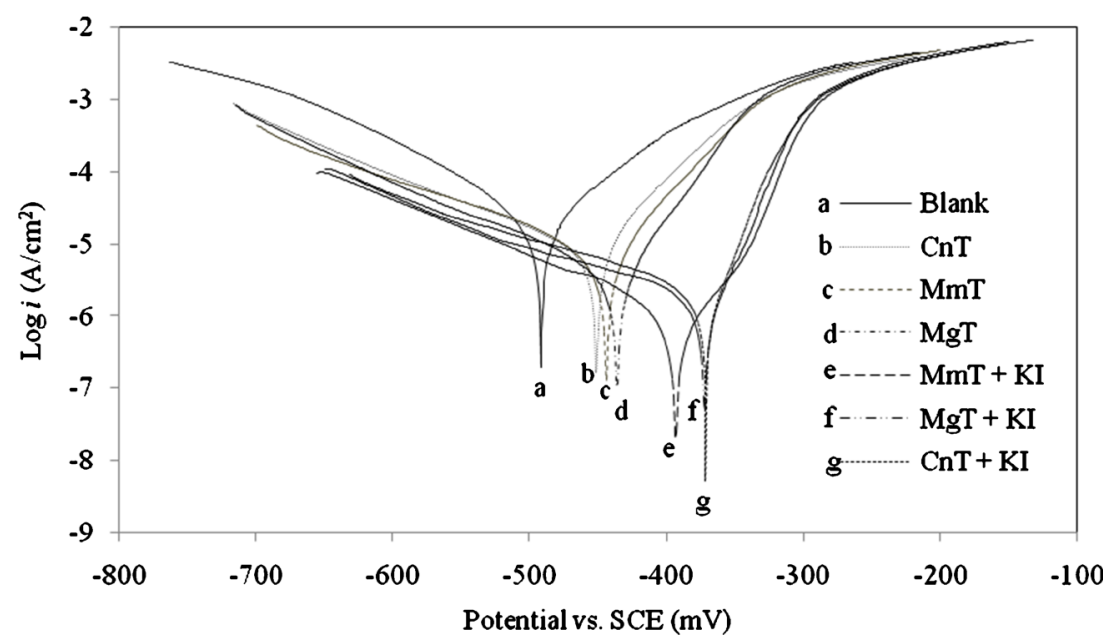

densities was enhanced as the iodide ions were introduced in both corrosive media containing these tannins. This provides an indication that a synergistic effect between these tannins and iodide ions has occurred. For all three tannins, the pronounced decrease in anodic current densities in the combination of these tannins and iodide ions was associated with the shift of corrosion potential $\left(\mathrm{E}_{\mathrm{corr}}\right)$ towards the anodic potential region, suggesting that these corrosion inhibitors mainly affect the anodic reactions (Ali et al. 2008). In other words, the oxidation process of metal dissolution is predominatly inhibited, and thus the corrosion process is slowed down. Moreover, the mass transfer process has taken place in all reactions, since the anodic gradients are higher for all analyses as compared to the cathodic regions. Therefore, all tannins are classified as mixed-type inhibitors with predominantly anodic effectiveness in both media, and the inhibitive performance of mangrove tannin with and without the addition of iodide ions is comparable to that of commercial mimosa and chestnut tannins.

\subsection{Electrochemical impedance spectroscopy measurements}

As shown in Figs. 3 and 4, an increase in the size of the semicircles was obtained in the presence of tannins alone, indicating the inhibition of the corrosion process. The size of the semicircles was further increased as the iodide ions were introduced into the corrosive media containing these tannins. All Nyquist plots at high frequencies obtained in all processes are not perfect semicircles, but are depressed. The depressed form of semicircles is often referred to as frequency dispersions which have been attributed to surface heterogeneities of structural or interfacial origins such as those found in adsorption processes (Kissi et al. 2006). From all electrochemical parameters obtained, it was observed that the introduction of
Fig. 2 Tafel plots of mild steel in $0.5 \mathrm{M} \mathrm{H}_{2} \mathrm{SO}_{4}$ in the absence and presence of mangrove tannin $(\mathrm{MgT})$, mimosa $(\mathrm{MmT})$ and chestnut (CnT) tannins alone and in combination with iodide ions

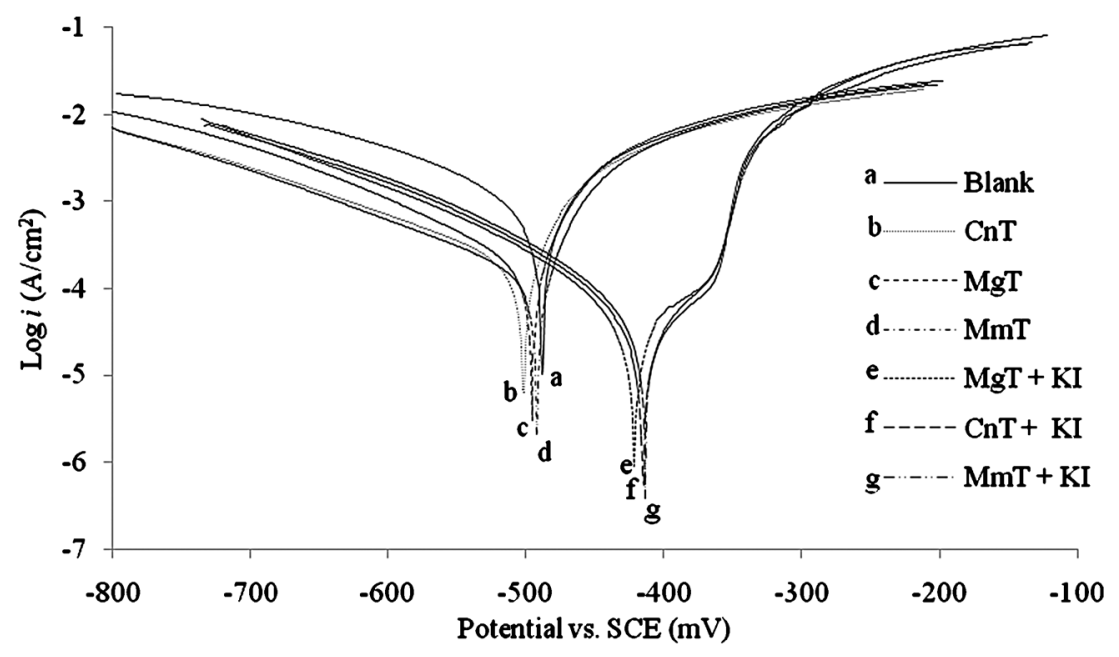


Table 1 Potentiodynamic polarisation parameters of mild steel in $0.5 \mathrm{M} \mathrm{HCl}$ and $0.25 \mathrm{M}$ $\mathrm{H}_{2} \mathrm{SO}_{4}$ in the absence and presence of $3 \mathrm{~g} \mathrm{l}^{-1} \mathrm{MgT}, 3 \mathrm{~g} \mathrm{l}^{-1} \mathrm{MmT}$ and $2 \mathrm{~g} \mathrm{l}^{-1} \mathrm{CnT}$ alone and in the combination with $0.1 \mathrm{M} \mathrm{KI}$

$M g T$ mangrove tannin, $M m T$ mimosa tannin, $C n T$ chestnut tannin

\begin{tabular}{|c|c|c|c|c|c|}
\hline System & $-\beta_{\mathrm{a}}\left(\mathrm{mV} \operatorname{dec}^{-1}\right)$ & $-\beta_{\mathrm{c}}\left(\mathrm{mV} \mathrm{dec}{ }^{-1}\right)$ & $\mathrm{E}_{\text {corr }}(\mathrm{mV})$ & $i_{\text {corr }}\left(\mu \mathrm{A} \mathrm{cm}^{-2}\right)$ & IE (\%) \\
\hline $\mathrm{HCl}$ & 95 & 123 & -469 & 158 & - \\
\hline $\mathrm{KI}$ & 41 & 157 & -354 & 56 & 65 \\
\hline $\mathrm{MgT}$ & 40 & 95 & -435 & 18 & 89 \\
\hline $\mathrm{MgT}+\mathrm{KI}$ & 35 & 91 & -372 & 10 & 94 \\
\hline $\mathrm{MmT}$ & 45 & 107 & -444 & 29 & 82 \\
\hline $\mathrm{MmT}+\mathrm{KI}$ & 62 & 68 & -393 & 9 & 94 \\
\hline $\mathrm{CnT}$ & 64 & 118 & -451 & 42 & 73 \\
\hline $\mathrm{CnT}+\mathrm{KI}$ & 40 & 72 & -380 & 11 & 93 \\
\hline $\mathrm{H}_{2} \mathrm{SO}_{4}$ & 86 & 144 & -486 & 1000 & - \\
\hline $\mathrm{KI}$ & 30 & 155 & -412 & 135 & 86 \\
\hline $\mathrm{MgT}$ & 40 & 116 & -496 & 219 & 78 \\
\hline $\mathrm{MgT}+\mathrm{KI}$ & 68 & 127 & -421 & 56 & 94 \\
\hline $\mathrm{MmT}$ & 45 & 177 & -493 & 200 & 80 \\
\hline $\mathrm{MmT}+\mathrm{KI}$ & 60 & 122 & -414 & 50 & 95 \\
\hline $\mathrm{CnT}$ & 52 & 144 & -502 & 209 & 79 \\
\hline $\mathrm{CnT}+\mathrm{KI}$ & 63 & 121 & -415 & 53 & 95 \\
\hline
\end{tabular}

tannins into the acid solution led to the increase in the charge transfer resistance $\left(R_{c t}\right)$ and reduction in the constant phase element (CPE), which became more pronounced as these tannins were combined with the iodide ions. The decrease in the CPE values normally results from the decrease in the dielectric constant and/or an increase in the double-layer thickness, which leads to a higher inhibition efficiency. In other words, this is due to the inhibitor adsorption onto the metal/electrolyte interface (Popova et al. 2003). The increase in $R_{c t}$ and the decrease in CPE values as shown in Table 2 are probably due to the replacement of water molecules by the iodide ions and tannin molecules on the electrode surface, as well as probably due to the increase in the double layer

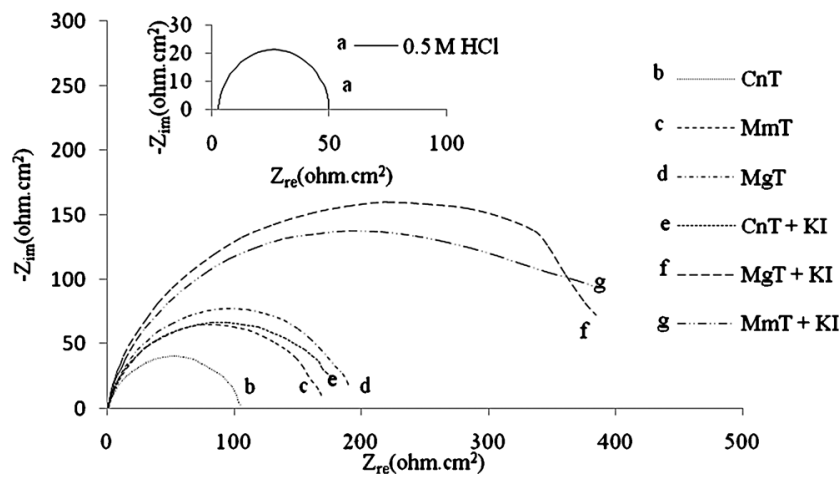

Fig. 3 Nyquist plots of mild steel in $0.5 \mathrm{M} \mathrm{HCl}$ in the absence and presence of mangrove tannin $(\mathrm{MgT})$, mimosa $(\mathrm{MmT})$ and chestnut $(\mathrm{CnT})$ tannins and in combination with iodide ions thickness as a consequence of the adsorption of these tannins and iodide ions.

4.3 Temperature studies of the corrosion inhibition effect of tannins and iodide ions

The effects of temperature were studied in order to evaluate the performance of tannins in combination with iodide ions on the nature of adsorption and activation processes. According to Bentiss et al. (2009), the effect of temperature on the inhibited acid-metal reaction is highly complex. This is due to the many changes that occur, such as the rapid etching and desorption of inhibitors on the metal surface. As the inhibitors were added into the corrosive medium, the \% IE values slightly decreased as the temperature increased. This phenomenon is probably due to the desorption process of the inhibitor from the metal surface (Cheng et al. 2007) or the decomposition and/or rearrangement of the inhibitor. Alternatively, it could also be due to the decrease in hydrogen evolution overpotential (Popova et al. 2003). Similar trends also have been observed for mimosa tannin and chestnut tannin (not shown).

These observations indicated that the energy barriers of the corrosion reactions increased as the inhibitors were introduced into the corrosive medium. The decrease in $\%$ IE values as the temperatures increased with higher $E_{a}$ values than in the absence of inhibitors often indicates that there is a formation of an adsorptive film which possesses a physical (electrostatic) type character (Popova et al. 2003). Moreover, the high values of $\mathrm{E}_{\mathrm{a}}$ will lower the corrosion current density, 
Fig. 4 Nyquist plots of mild steel in $0.25 \mathrm{M} \mathrm{H}_{2} \mathrm{SO}_{4}$ in the absence and presence of mangrove tannin $(\mathrm{MgT})$, mimosa $(\mathrm{MmT})$ and chestnut $(\mathrm{CnT})$ tannins and in combination with iodide ions

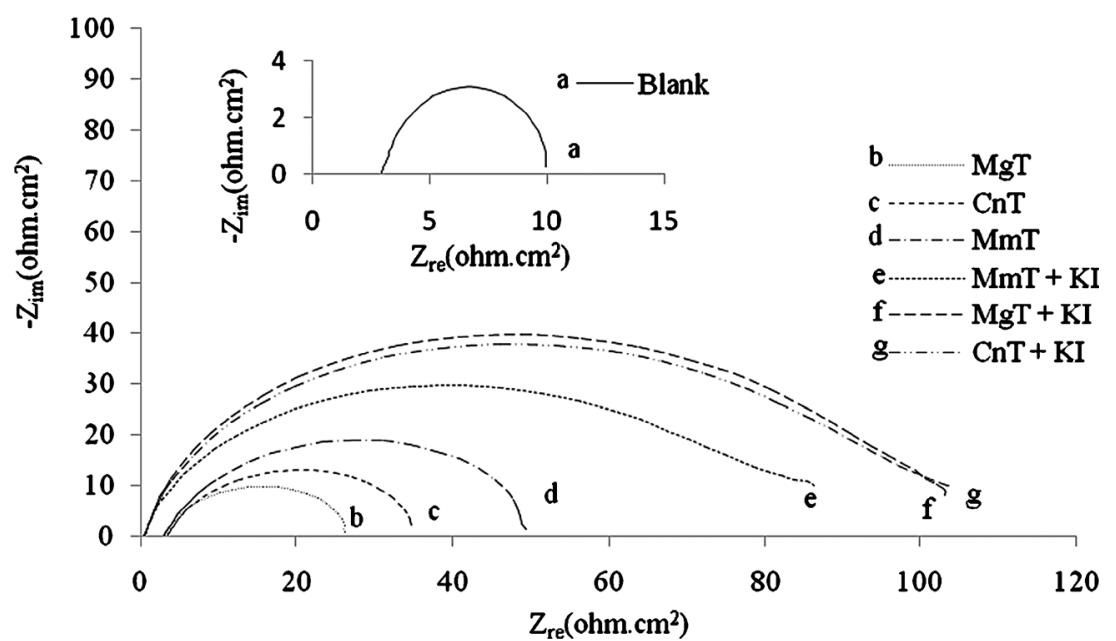

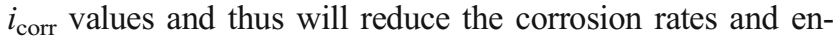
hance the inhibition efficiencies of the inhibitors. The increase in $\mathrm{E}_{\mathrm{a}}$ values has been shown to indicate a strong adsorption of inhibitor molecules on the metal surface (Singh et al. 2012). According to Orubite and Oforka (2004), an $\mathrm{E}_{\mathrm{a}}$ value that is around $40-80 \mathrm{~kJ} \mathrm{~mol}^{-1}$ is suggested to obey the physical adsorption (physisorption) mechanism. In all analyses, the $\mathrm{E}_{\mathrm{a}}$ values were within this range except for those values obtained in $0.5 \mathrm{M} \mathrm{HCl}$ medium, which were more than $80 \mathrm{~kJ} \mathrm{~mol}^{-1}$. This indicated that the mode of inhibitor adsorption for this medium leans more towards chemisorption. Besides, the enthalpy, $\Delta H$ values of all analyses were positive,

Table 2 Electrochemical impedance spectroscopy parameters of mild steel in $0.5 \mathrm{M} \mathrm{HCl}$ and $0.25 \mathrm{M} \mathrm{H}_{2} \mathrm{SO}_{4}$ in the absence and presence of $3 \mathrm{~g}^{-1} \mathrm{MgT}, 3 \mathrm{~g}^{-1} \mathrm{MmT}$ and $2 \mathrm{~g}^{-1} \mathrm{CnT}$ alone and in combination with $0.1 \mathrm{M} \mathrm{KI}$

\begin{tabular}{llccl}
\hline System & $\mathrm{R}_{\mathrm{s}}\left(\Omega \mathrm{cm}^{2}\right)$ & $\mathrm{CPE}\left(\mu \mathrm{F} \mathrm{cm}^{-2}\right)$ & $\mathrm{R}_{\mathrm{ct}}\left(\Omega \mathrm{cm}^{2}\right)$ & $\mathrm{IE}(\%)$ \\
\hline $\mathrm{HCl}$ & 2.175 & 415.3 & 30.4 & - \\
$\mathrm{KI}$ & 1.813 & 106.8 & 100.2 & 70 \\
$\mathrm{MgT}$ & 2.617 & 133.1 & 189.7 & 84 \\
$\mathrm{MgT}+\mathrm{KI}$ & 2.496 & 86.6 & 397.3 & 92 \\
$\mathrm{MmT}$ & 2.743 & 158.9 & 168.0 & 82 \\
$\mathrm{MmT}+\mathrm{KI}$ & 2.465 & 81.4 & 387.7 & 92 \\
$\mathrm{CnT}$ & 2.837 & 187.8 & 104.1 & 71 \\
$\mathrm{CnT}+\mathrm{KI}$ & 2.591 & 92.9 & 175.0 & 83 \\
$\mathrm{H}{ }_{2} \mathrm{SO}$ & 2.965 & 643.2 & 7.0 & - \\
$\mathrm{KI}$ & 2.828 & 203.1 & 56.5 & 88 \\
$\mathrm{MgT}$ & 2.967 & 502.2 & 23.6 & 70 \\
$\mathrm{MgT}+\mathrm{KI}$ & 2.676 & 128.2 & 103.1 & 93 \\
$\mathrm{MmT}$ & 3.044 & 420.7 & 46.2 & 85 \\
$\mathrm{MmT}+\mathrm{KI}$ & 2.094 & 177.8 & 84.6 & 92 \\
$\mathrm{CnT}$ & 3.455 & 483.4 & 31.5 & 78 \\
$\mathrm{CnT}+\mathrm{KI}$ & 2.488 & 150.5 & 100.2 & 93 \\
\hline
\end{tabular}

$M g T$ mangrove tannin, $M m T$ mimosa tannin, $C n T$ chestnut tannin reflecting that the metal dissolution processes were endothermic. The rise in $\Delta \mathrm{H}$ values may be attributed to the presence of energy barriers for the adsorption reaction (Tebbji et al. 2007). The negative values of entropy, $\Delta S$ as obtained in both media indicated that the activated complex in the rate determining step represents an association rather than a dissociation step. The increased $\Delta \mathrm{S}$ values as compared to those obtained in the blank solution is due to the reduction in hydrogen ions discharge by adsorbed inhibitor molecules, which consequently prevent the hydrogen ions from forming adsorbed hydrogen atoms. This causes the system to pass from an orderly to more random arrangement, and hence an increase in the $\Delta \mathrm{S}$ values (Singh et al. 2012).

Table 3 The effect of temperature on the corrosion inhibition of mild steel in in $0.5 \mathrm{M} \mathrm{HCl}$ and $0.25 \mathrm{M} \mathrm{H}_{2} \mathrm{SO}_{4}$ solutions in the absence and presence of $0.3 \mathrm{~g}^{-1}$ mangrove tannin (MgT) and $0.1 \mathrm{M} \mathrm{KI}$

\begin{tabular}{llrcl}
\hline System & Temperature (K) & CR (mpy) & $i_{\text {corr }}\left(\mu \mathrm{A} \mathrm{cm}{ }^{-2}\right)$ & IE (\%) \\
\hline $\mathrm{HCl}$ & 300 & 72.9 & 158.0 & - \\
& 313 & 201.5 & 437.0 & - \\
& 323 & 289.2 & 627.0 & - \\
& 333 & 450.6 & 977.0 & - \\
$\mathrm{MgT}+\mathrm{KI}$ & 300 & 4.6 & 10 & 94 \\
& 313 & 19.5 & 42.3 & 90 \\
& 323 & 47.5 & 103.0 & 84 \\
& 333 & 99.6 & 215.9 & 78 \\
$\mathrm{H}_{2} \mathrm{SO}_{4}$ & 300 & 461.2 & 1000.0 & - \\
& 313 & 655.8 & 1422.0 & - \\
& 323 & 864.7 & 1874.9 & - \\
& 333 & 1041.7 & 2258.9 & - \\
$\mathrm{MgT}^{2}+\mathrm{KI}$ & 300 & 25.8 & 56.0 & 94 \\
& 313 & 75.2 & 163.1 & 89 \\
& 323 & 168.8 & 366.1 & 81 \\
& 333 & 221.1 & 479.4 & 79 \\
\hline
\end{tabular}


Table 4 The activation parameters of the dissolution reaction of mild steel in $0.5 \mathrm{M} \mathrm{HCl}$ and $0.25 \mathrm{M} \mathrm{H}_{2} \mathrm{SO}_{4}$ solutions in the absence and presence of $3 \mathrm{~g} \mathrm{l}^{-1} \mathrm{MgT}, 3 \mathrm{~g} \mathrm{l}^{-1} \mathrm{MmT}$ and $2 \mathrm{~g}^{-1} \mathrm{CnT}$ and $0.1 \mathrm{M} \mathrm{KI}$

\begin{tabular}{lccl}
\hline Sample & $\mathrm{E}_{\mathrm{a}}\left(\mathrm{kJ} \mathrm{mol}^{-1}\right)$ & $\Delta \mathrm{H}\left(\mathrm{kJ} \mathrm{mol}^{-1}\right)$ & $\Delta \mathrm{S}\left(\mathrm{J} \mathrm{mol}^{-1} \mathrm{~K}^{-1}\right)$ \\
\hline $\mathrm{HCl}$ & 67.14 & 64.51 & -909.74 \\
$\mathrm{MgT}$ & 98.51 & 95.89 & -828.09 \\
$\mathrm{MmT}$ & 112.90 & 110.28 & -748.78 \\
$\mathrm{CnT}$ & 103.12 & 100.50 & -813.13 \\
$\mathrm{H}_{2} \mathrm{SO}_{4}$ & 20.81 & 18.18 & -133.28 \\
$\mathrm{MgT}$ & 56.00 & 53.37 & -39.32 \\
$\mathrm{MmT}$ & 59.38 & 56.76 & -28.77 \\
$\mathrm{CnT}$ & 57.28 & 54.65 & -35.42 \\
\hline
\end{tabular}

$M g T$ mangrove tannin, $M m T$ mimosa tannin, $C n T$ chestnut tannin

\section{Conclusions}

1. All tannins gave satisfactory inhibition efficiencies in all tested methods, and they were further improved with the addition of iodide ions.

2. Tannins synergised by iodide ions acted as mixed-type inhibitors with predominantly anodic effectiveness.

3. Mangrove tannin showed comparable inhibitive properties to those of commercial mimosa and chestnut tannins.

Acknowledgments The authors acknowledge the assistance proffered by technical staff and laboratory assistants of the School of Chemical Sciences, Universiti Sains Malaysia (USM) for the laboratory facilities and technical assistance.

Funding The authors express their gratitude to the Ministry of Higher Education of Malaysia (MOHE) for financial support from MyMaster sponsorship and Universiti Sains Malaysia under Research University Grant (1001/PKIMIA/811213).

\section{References}

Afidah AR (2009) Mangrove tannin as a green corrosion inhibitor of steel: a comprehensive study. VDM Verlag, Saarbrücken

Ali SA, Al-Muallem HA, Rahman SU, Saeed MT (2008) Bisisoxazolidines: a new class of corrosion inhibitors of mild steel in acidic media. Corros Sci 51:1628-1635
Bentiss F, Jama C, Mernari B, Attari HE, Kadi LE, Lebrini M, Traisnel M, Lagrenée M (2009) Corrosion control of mild steel using 3,5-bis(4methoxyphenyl)-4-amino-1,2,4-triazole in normal hydrochloric acid medium. Corros Sci 51:1628-1635

Cheng S, Liu T, Chang X, Yin Y (2007) Carboxymethylchitosan as an ecofriendly inhibitor for mild steel in $1 \mathrm{M} \mathrm{HCl}$. Mater Lett 61:32763280

Davis JR (2000) Corrosion: understanding the basics. The Materials Information Society, Ohio

Kissi M, Bouklah M, Hammouti B, Benkaddour M (2006) Establishment of equivalent circuit from electrochemical impedance spectroscopy study of corrosion inhibition of steel by pyrazine in sulphuric acid solution. Appl Surf Sci 252:4190-4197

Orubite KO, Oforka NC (2004) Inhibition of the corrosion of mild steel in hydrochloric acid solutions by the extracts of leaves of Nypa fructicans Wurmb. Mater Lett 58:1768-1772

Pavithr MK, Venkatesh TV, Vathsal K, Nayan KO (2010) Synergistic effect of halide ions on improving corrosion inhibition behaviour of benzisothiozole-3-piperizine hydrochloride on mild steel in $0.5 \mathrm{M}$ $\mathrm{H}_{2} \mathrm{SO}_{4}$ medium. Corros Sci 52:3811-3819

Popova A, Sokolova E, Raicheva S, Christov M (2003) AC and DC study of the temperature effect on mild steel corrosion in acidic media in the presence of benzimidazole derivatives. Corros Sci 45:33-58

Prabhu RA, Venkatesha TV, Shanbhag AV, Praveen BM, Kulkarni GM, Kalkhambkar RG (2008) Quinol-2-thione compounds as corrosion inhibitors for mild steel in acid solution. Mater Chem Phys 108:283289

Rahim AA, Kassim J (2008) Recent development of vegetal tannins in corrosion protection of iron and steel. Recent Patents Mater Sci 1: 223-231

Rahim AA, Rocca E, Steinmetz J, Kassim MJ, Ibrahim MS (2007) Mangrove tannins and their flavonoid monomers as alternative steel corrosion inhibitors in acidic medium. Corros Sci 49:402-417

Rahim AA, Rocca E, Steinmetz J, Kassim MJ, Ibrahim MS (2008) Inhibitive action of mangrove tannins and phosphoric acid on prerusted steel via electrochemical methods. Corros Sci 50:1546-1550

Rahim AA, Kassim MJ, Rocca E, Steinmetz J (2011) Mangrove (Rhizophora apiculata) tannins: an eco-friendly rust converter. Corros Eng Sci Technol 46:425-431

Raja PB, Sethuraman MG (2008) Natural products as corrosion inhibitor for metals in corrosive media - a review. Mater Lett 62:113-116

Singh AK, Shukla SK, Quraishi MA, Ebenso EE (2012) Investigation of adsorption characteristics of $\mathrm{N}, \mathrm{N}^{\prime}-[($ methylimino)dimethylidyne $]$ di2,4-xylidine as corrosion inhibitor at mild steel/sulphuric acid interface. J Taiwan Inst Chem Eng 43:463-472

Syed S (2006) Atmospheric corrosion of materials. Emirates J Eng Res $11: 1-24$

Tebbji K, Faska N, Tounsi A, Oudda H, Benkaddour M, Hammouti B (2007) The effect of some lactones as inhibitors for the corrosion of mild steel in $1 \mathrm{M}$ hydrochloric acid. Mater Chem Phys 106:260-267

Winston R (2000) Uhlig's corrosion handbook, 2nd edn. Wiley, Ottawa 